\title{
Practical considerations for integral approach of people with intellectual disabilities
}

\author{
Javier A. Magaña-Gómez ${ }^{1 *}$, Fidel A. Domínguez-Castro ${ }^{1}$, Ingrid Y. Álvarez-Parra ${ }^{1}$, Lizbeth Espinoza-Solís ${ }^{1}$, \\ Carla E. Angulo-Rojo², Rafael Castro-Pérez ${ }^{3}$ and Gisela Duarte-De la Peña ${ }^{4}$ \\ ${ }^{1}$ Research Laboratory, School of Nutrition and Gastronomy; ${ }^{2}$ Laboratory of Neurosciences, Centro de Investigación Aplicada a la Salud Pública; \\ ${ }^{3}$ Faculty of Psychology, Universidad Autónoma de Sinaloa; ${ }^{4}$ Nutrition Program, Unidad Regional Culiacán, Universidad Autónoma de Occidente. \\ Sinaloa, México
}

\begin{abstract}
People with some disability have worse health prognosis due to biological complications, inadequate access to health services, higher economic expenses, and difficulties in the communication of sensations and perceptions. Therefore, therapeutic strategies and the knowledge generated through scientific research are useful to improve their quality of life. This review addresses the most relevant issues for professionals who are interested in this field, offering the most accepted definition with its implications up to the description of the conditions that should be considered when giving a treatment, conducting research, raising public policies, modifying the health schemes, and availability of supports, among others. For this, the different domains of intellectual capacity, as well as the affected biological systems, are presented to carry out practical actions and generate objective knowledge that enhances the quality of life of people with intellectual disabilities.
\end{abstract}

Key words: Intellectual disability. Health. Therapeutic. Approach.

\section{Consideraciones prácticas para el abordaje integral de personas con discapacidad intelectual}

\section{Resumen}

Las personas con discapacidad intelectual tienen un mal pronóstico de salud por las complicaciones biológicas, el acceso limitado a servicios de salud, mayores gastos económicos y dificultades en la comunicación de sensaciones y percepciones. Por ello, las estrategias terapéuticas, así como el conocimiento generado a través de investigaciones científicas, son determinantes para mejorar su calidad. La presente revisión aborda los temas más relevantes para profesionales que se interesan en este campo, ofreciendo la definición más aceptada con sus implicaciones hasta la descripción de las condiciones que deben considerarse al momento de dar un tratamiento, realizar investigaciones, plantear políticas públicas, modificar los esquemas de salud y disponibilidad de apoyos, entre otros. Para ello se presentan los diferentes dominios de la capacidad intelectual, así como los sistemas biológicos afectados, a fin de realizar acciones prácticas y generar conocimiento objetivo que mejore la calidad de las personas con discapacidad intelectual.

Palabras clave: Discapacidad intelectual. Salud. Tratamiento. Abordaje.

\section{Correspondence:}

Javier A. Magaña Gómez

E-mail: jmagana@uas.edu.mx
Available online: 09-08-2019 Rev Mex Neuroci. 2019;20(4):186-193 www.revmexneurociencia.com 1665-5044/@ 2019. Academia Mexicana de Neurología A.C. Published by Permanyer México. This is an Open Access article under the terms of the CC BYNCND license(http://creativecommons.org/licenses/by-nc-nd/4.0/). 


\section{Introduction}

Disability is a condition that impacts both individually and collectively, in areas as diverse as health, economy, administration, and politics, due to the implications for both the individual and the family and society that surround it ${ }^{1}$. People with disabilities tend to have the worst health scenarios and insufficient access to health-care services, with respect to the general population. They present high rates of health risks including physical inactivity, obesity, smoking, and inadequate emotional support. They also have a high prevalence of chronic conditions such as diabetes, high blood pressure, arthritis, chronic pain, and heart disease. The combination of these conditions makes persons with disabilities vulnerable to a continuous detriment in their functioning and quality of life, making this issue a matter of social interest ${ }^{2}$.

The concept of disability is difficult to define since it has not been used consistently throughout history and can be approached from multiple perspectives, from strictly medical and rehabilitation to other social, educational, work, public health, or even moral. Thus, many concepts can fit in "disability", such as those problems caused by the loss or abnormality of any body part, or limitations in their function, rehabilitation needs, and difficulties in carrying out usual activities in a specific social and temporal context. Other causes could be included, such as the restrictions on social participation, barriers in mobility or social integration, and problems in the development of social roles for physical or mental causes and in the assumption of responsibilities or in the self-management ${ }^{3}$.

At present, the most accepted definition of disability is from the American Association of Intellectual and Developmental Disabilities (AAIDD), termed as the expression of limitations in the functioning of the individual in a social context, which represents a substantial disadvantage and often has their origin in a health condition (disorder or disease). It can be stated that disability is a generic term that encompasses deficiencies, limitations in activity, and restrictions on participation. Furthermore, it expresses the negative aspects of the interaction between an individual with health problems and their physical and social environment ${ }^{4}$. In Mexico, according to the NOM-015-SSA3-2012 for comprehensive care for people with disabilities, it is defined as hearing, intellectual, neuromotor, or visual impairment, whether permanent or temporary, which limits the ability to perform one or more daily life activities (Fig. 1). For the present review, the one of interest is the intellectual disability characterized by limitations in mental functioning and the adaptive behavior of the environment ${ }^{5}$.

\section{Intellectual disability}

During the past 200 years, the concept of intellectual disability has evolved from being imbecility to mental weakness, mental disability, and subnormality. At present, it is identified with the widespread use of the concept of "mental retardation" although it is being replaced by intellectual disability ${ }^{6}$. Over the years, numerous definitions of intellectual disability have been proposed, reviewed, and analyzed, due to it is a condition approached by professionals from diverse disciplines and, therefore, with very different perspectives. Medicine was one of the first professional areas that dealt with intellectual disability; consequently, the earlier definitions accentuated the biological or medical criteria. However, for other disciplines such as education or different therapies, these were not particularly useful. Besides, the culture also affected the way of interpreting disability. These observations led to the need to identify the universal aspects of disability considering the cultural and linguistic differences, integrating them in the development of a definition and classification of disability?

Having a unified and international definition and classification of intellectual disability are useful for sharing and comparing information through epidemiological, sociological, or statistical studies. At present, it is a classification of health and health-related domains to describe changes in body function and structure, what a person with a health condition can do in a standard environment (their level of capacity), as well as what they do in their usual environment (their level of performance). Finally, health is the element that relates to the previous two.

Changes in the terminology used to define intellectual disability have a differential influence on society. The oldest definitions were based primarily on the concept of the degree of inherited intelligence, establishing criteria about how to measure intelligence and how to utilize the results to classify individuals with intellectual disabilities. Nowadays, the definitions try to change the way people think about intellectual disability. For this, it does not emphasize the disabilities of the individual, but the environment and the necessary support for their learning and for the person to improve the level of quality of life. The accepted definition of intellectual disability from the AADID states that "Intellectual disability is a disability characterized by significant limitations in both intellectual functioning and in adaptive behavior, which covers many everyday social and practical skills. This disability 


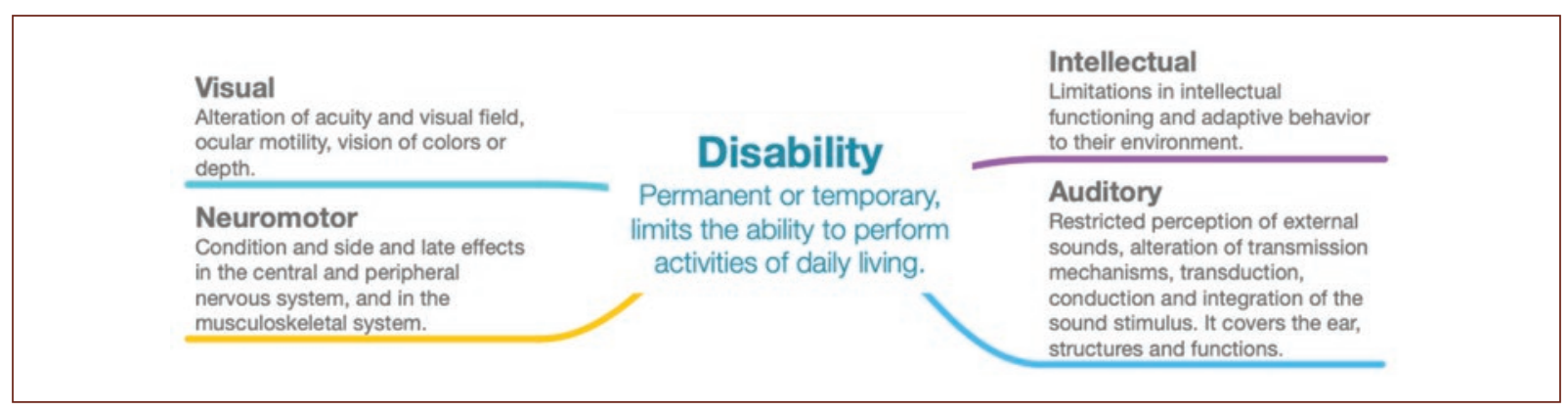

Figure 1. Definition and classification of disability according to NOM-015-SSA3-2012.

originates before the age of $18^{8}$ ". For the application of this definition, some assumptions must be considered:

1. Limitations on current functioning should be taken into account in the context of typical community environments of peers in age and culture.

2. A valid assessment considers cultural and linguistic diversity, as well as differences in communication and sensory, motor, and behavioral factors.

3. Within an individual, limitations often go hand in hand with strengths.

4. An essential purpose of describing the limitations is to develop a profile of the indispensable supports.

5. With appropriate personalized supports over a sustained period, the life functioning of the person with an intellectual disability generally will improve.

The Diagnostic and Statistical Manual of Mental Disorders (DSM-5) defines it in total agreement with the AADID, eliminating the use of the Mental retardation concept, providing the definition of the following domains to be considered for evaluation and above all to determine the levels of severity, and also decreasing reliance on the intelligence quotient $(\mathrm{IQ})$ scores for the categories, as was done in the DSM-IV9:

1. Conceptual domain (academic): it includes the competence in memory, language, reading, writing, mathematical reasoning, and the acquisition of practical knowledge, among others.

2. Social domain: it implies the recognition of the thoughts, feelings and experience of others, empathy, interpersonal communication skills for friendship, and social criteria, among others.

3. Practical domain: it includes learning and autonomy in different areas of daily life, such as personal care, responsibility, and organization in school or work tasks, money management, leisure time and recreation, and self-control of their behaviors, among others.

The term intellectual disability, on others such as mental retardation, is better aligned with current professional practices that focus on functional behaviors and contextual factors, provides a logical basis for the provision of individualized supports based on a social framework. It is less offensive to people with disabilities and is more consistent with international terminology. Some authors, under the influence of DSM-IV, still consider as part of the definition of intellectual disability a value equal to or $<70$ referring to the intellectual coefficient, as a criterion for diagnosis, which indicates some limitations in intellectual functioning and adaptive behavior. Although intellectual disability exists independently in certain conditions, there are some that frequently present it, such as Down syndrome, Rett syndrome, X-fragile syndrome, autism spectrum disorder, Prader-Willi syndrome, Angelman, Williams syndrome, and inborn errors of metabolism. However, rather than causes of the condition, these conditions do not have a necessary link with the classification criteria and are present in the minority of people diagnosed ${ }^{10}$.

\section{Epidemiology of disability}

The United Nations Organization estimated that there are around 600 million people in the world with different types of disabilities, of which 400 million are in low-income countries and approximately 60 million in Latin America and the Caribbean. On the other hand, the World Health Organization and the Pan American Health Organization (WHO/PAHO) estimates that $6-10 \%$ of the general population is people with disabilities. However, the disability affects not only the person but also the family and the community, involving approximately $25 \%$ of the total population ${ }^{11}$. Regarding intellectual disability, in particular, it is considered frequent, with an approximate prevalence of $1-4 \%$ and a high impact on individual functioning. In Latin America, the prevalence can be 4 times higher due to its association with factors such as malnutrition, obstetric and perinatal complications, prematurity, lead poisoning, and infections of the central nervous system ${ }^{12}$. 
The official reports on disability in Mexico come exclusively from the Population and Housing Census, which does not represent a diagnostic measurement but provide data. The 2010 census included an expanded questionnaire that reports to the population that presents some disability, seen this from the focus of limitations in the activity ${ }^{13}$. That is, people with some restriction to attend to personal care, walk and move, listen, talk or communicate, pay attention, see, or with some mental limitation, were counted. Depending on this report, disability reached $5.1 \%$ of the total population, that is, around $5,739,270$ Mexicans. However, this registry includes many other conditions, which do not allow observing a specific figure of intellectual disability. However, as a public health issue, the underestimation of intellectual disability in Mexico is emphasized. Epidemiological research and not only general census data would confirm the existence of up to 4 million people with intellectual disabilities in Mexico, assuming a prevalence similar to the universal one of $1-4 \%$.

\section{Classification of intellectual disability}

Intellectual disability is a heterogeneous condition, so it is essential to evaluate the difficulties and strengths of functioning in each to propose an appropriate therapeutic plan. For this reason, it is important to diagnose it, considering an integral evaluation of the intellectual coefficient and the adaptive level, as well as the evaluation of the functioning of the people who suffer it. For this, it is necessary taking into account not only their health condition (disorder or illness) but also their functions and body structures, their activities and participation in the community, without forgetting their context.

The classification of intellectual disability is a difficult task, which may vary according to the aspect evaluated and the interests of the classification (Table 1). Educators use different terms to designate to the various levels of intellectual disability. For many years, students with intellectual disabilities were classified as educable mentally retarded (EMR) or trainable mentally retarded (TMR), referring to the levels of mild and moderate intellectual disability, respectively. This system did not consider children with severe and profound intellectual disabilities because they were often excluded from public education. Even though at present it is still possible to find the EMR and TMR classifications, most educators consider them inappropriate due to suggest the existence of predetermined limits of intellectual functioning.

Conventionally, IQ scores have been the primary criterion for classifying people with intellectual disabilities as mild, moderate, severe, and profound severity rating.
However, the score of upper and lower limits of each level is set according to the test used, which indicates the lack of accuracy of the intelligence assessments and the importance of the clinical judgment to determine the level of severity. Overtime, the weight of IQ scores has been reduced thanks to the development of other dimensions that show importance in the interaction of people and their environments such as adaptive behaviors and the context of social roles. The classification according to the need for support focuses on the needs of people, with the aim of providing strategies for intervention. The aspects that must be taken into account to classify an individual according to their need for support are the intellectual capacity, adaptive behavior, participation, health, interaction, and social roles. At present, disability, in general, is classified according to the framework given by the International Classification of Functioning, Disability and Health, commonly known as ICF, developed by the WHO to measure the health and disability of the individual. It classifies human functioning considering some components: (1) body functions, referring to the physiological functions of body systems, (2) body structures, anatomical parts of the body such as organs, limbs, and their components, (3) activities and participation, where activity is the execution of a task or action by an individual and participation is involvement in a life situation, and (4) environmental factors that make up the physical, social, and attitudinal environment in which people live and conduct their lives ${ }^{14}$.

\section{Problems in health and health care}

People with intellectual disabilities form a heterogeneous population, with different functional levels and needs. Most experiment a stressing time when visiting the health service, due to the difficulties in communicating and correctly processing large amounts of information and technical vocabulary from the health personnel. They may have trouble giving temporary referrals, such as when they feel unwell or when was their last medical visit. They also have problems in expressing "correctly" when they go through states of discomfort or pain and could show it in the form of less adapted behaviors such as screaming, aggression, self-aggression, and hyperactivity, among others. Some people have difficulty processing sound, visual, and even tactile stimuli, being a challenge for them to tolerate situations in which the environment presents a large number of stimuli. For these reasons, it is necessary for health professionals to facilitate collaboration during the therapeutic visit, considering the difficulties that may arise and generate negative behavior ${ }^{16}$. 
Table 1. Categories used for the classification of intellectual disability

\begin{tabular}{|c|c|}
\hline $\begin{array}{l}\text { Categories of } \\
\text { classification }\end{array}$ & Description \\
\hline By etiology & $\begin{array}{l}\text { Prenatal causes: } \\
\text { - Chromosomal alterations } \\
\text { - Inborn errors of metabolism } \\
\text { - Alterations of brain development } \\
\text { Perinatal causes: } \\
\text { - Intrauterine disorders } \\
\text { - Neonatal disorders } \\
\text { Postnatal causes: } \\
\text { - Cranial trauma } \\
\text { - Infections } \\
\text { - Degenerative disorders } \\
\text { - Seizure disorders } \\
\text { - Toxic-metabolic disorders } \\
\text { - Malnutrition } \\
\text { - Lack of social environment }\end{array}$ \\
\hline $\begin{array}{l}\text { By intellectual } \\
\text { capacity }\end{array}$ & $\begin{array}{l}\text { Interpretation according to the } 10 \text { score obtained in the Wechsler tests: } \\
\text { > 130: very superior } \\
\text { 120-129: superior } \\
\text { 110-119: high average } \\
\text { 90-109: average } \\
\text { 80-89: low average } \\
\text { 70-79: borderline } \\
\text { <69: extremely low }\end{array}$ \\
\hline $\begin{array}{l}\text { According to the } \\
\text { need for educational } \\
\text { support }\end{array}$ & $\begin{array}{l}\text { - Borderline intellectual disability: they show a delay in learning or some concrete learning difficulties. Many } \\
\text { children from a disadvantaged socio-cultural environment could be included } \\
\text { - Mild intellectual disability: it is the majority group, not clearly deficient. They have greater difficulty with } \\
\text { subjects such as reading, writing, and mathematics. Minimal delay in areas in perceptual and motor areas } \\
\text { but can develop social and communication skills } \\
\text { - Moderate intellectual disability: most show a significant developmental delay during preschool age. When } \\
\text { they grow up, the differences in intellectual, social, and general motor development that separates these } \\
\text { children from those without disabilities often increase. They present an acceptable motor development and } \\
\text { can acquire basic pre-technological skills to perform some work } \\
\text { - Severe intellectual disability: in this category, people generally need protection or help, since their level of } \\
\text { autonomy, both social and personal, is very poor. They usually present a significant psychomotor impairment. They } \\
\text { can learn some communication system, but their oral language will always be very poor and their comprehension } \\
\text { very limited. Autonomy in displacement, cleanliness, feeding, and other personal care activities is hardly achieved } \\
\text { - Profound intellectual disability: they present a serious deterioration in the sensory-motor and communication } \\
\text { aspects. Personal autonomy is seriously affected to the degree of not being able to take care of their } \\
\text { physical needs, partially or totally lacking independent mobility, or requiring specialized care } 24 \mathrm{~h} \text { a day }\end{array}$ \\
\hline For support needs & $\begin{array}{l}\text { - Intermittent: support in "the occasions that are necessary," characterized by its episodic short-term nature } \\
\text { (for example, supports necessary in lifetime transitions such as loss of work or acute medical crises) } \\
\text { - Limited: characterized by consistency overtime, time constraint, but not of an intermittent nature, requires } \\
\text { fewer support members and less costs than more intense levels of support (e.g., support for transport) } \\
\text { - Extended: characterized by performing in some environments (school, work, and home) and has no time limit } \\
\text { (long-term support and life in the home) } \\
\text { - Total: high intensity characterized by its permanence and nature of life support, usually requires more support } \\
\text { members }\end{array}$ \\
\hline
\end{tabular}

10: intelligence quotient

(Adapted from Muñoz-Quesada, et al., 2017) ${ }^{15}$.

People with intellectual disabilities have a different profile of health need and higher rates of mortality and morbidity, as well as an increase in the use of health services. Higher rates of prevalence and risk have been found for important diseases such as epilepsy, diabetes, chronic constipation, human immunodeficiency virus, sexually transmitted diseases, gastrointestinal reflux, dementia, gastrointestinal cancer, thyroid disease, osteoporosis, allergies, cerebral palsy, different genetic syndromes, and genitourinary system diseases, among others ${ }^{17}$. The mental health problems and challenging behaviors that these people show, make them one of the most medicated groups in society ${ }^{18}$.

People with intellectual disabilities have, for various reasons, more risk of presenting medical pathologies compared to people without disabilities (Table 2). This fact is related to different factors such as styles and 
Table 2. Principal health problems in people with intellectual disabilities and general recommendations

\begin{tabular}{|c|c|c|}
\hline Affected system & Principal problems & Recommendation for health area staff \\
\hline Respiratory diseases & Pneumonia aspirative & $\begin{array}{l}\text { Attention in textures and food consistency in people with } \\
\text { severe and profound intellectual disabilities }\end{array}$ \\
\hline Cardiovascular diseases & $\begin{array}{l}\text { Aortic insufficiency } \\
\text { Mitral insufficiency }\end{array}$ & $\begin{array}{l}\text { Prevention of risk factors such as obesity, sedentary lifestyle, } \\
\text { high blood pressure, and dyslipidemias }\end{array}$ \\
\hline Digestive diseases & Constipation & $\begin{array}{l}\text { Promotion of mobility and right hydration with a complete and } \\
\text { high-fiber diet }\end{array}$ \\
\hline Infectious diseases & $\begin{array}{l}\text { Pneumonia } \\
\text { Endocarditis } \\
\text { Urinary tract infection }\end{array}$ & $\begin{array}{l}\text { Correct washing of hands } \\
\text { Consider immune deficits }\end{array}$ \\
\hline Genitourinary diseases & $\begin{array}{l}\text { Testicular neoplasia in men with } \\
\text { severe intellectual disability }\end{array}$ & General examination of genitalia periodically \\
\hline $\begin{array}{l}\text { Obstetric and gynecological } \\
\text { diseases }\end{array}$ & $\begin{array}{l}\text { Dysmenorrhea, menorrhagia, and } \\
\text { amenorrhea }\end{array}$ & $\begin{array}{l}\text { Pay special attention to hygiene problems associated with } \\
\text { menstruation }\end{array}$ \\
\hline Neurological diseases & Epilepsia & $\begin{array}{l}\text { Need to use more than one drug for the control of the crisis } \\
\text { considering side effects (constipation, gingival hypertrophy, } \\
\text { and excessive sedation) and drug interactions with other } \\
\text { treatments }\end{array}$ \\
\hline Sensory problems & Vision and hearing problems & Revision of auditory ducts \\
\hline Endocrine diseases & $\begin{array}{l}\text { Diabetes mellitus } \\
\text { Hypothyroidism }\end{array}$ & $\begin{array}{l}\text { Modify lifestyles such as avoiding inappropriate diets, to } \\
\text { prevent obesity and consider the influence of certain } \\
\text { psychotropic drugs such as some atypical antipsychotics } \\
\text { Have control over the treatment of lithium salts }\end{array}$ \\
\hline Oncological diseases & $\begin{array}{l}\text { Gastrointestinal neoplasia (esophagus, } \\
\text { stomach, and bile ducts) }\end{array}$ & $\begin{array}{l}\text { Avoid high-fat diets and decrease other risk factors such as } \\
\text { gastroesophageal reflux and constipation with correct eating } \\
\text { habits }\end{array}$ \\
\hline Bucodental diseases & $\begin{array}{l}\text { Loss of teeth } \\
\text { Gingival pathology } \\
\text { Malocclusion problems }\end{array}$ & $\begin{array}{l}\text { Correct dental hygiene } \\
\text { Dental treatments with fluoride regularly }\end{array}$ \\
\hline
\end{tabular}

living conditions (obesity, restricted diets, smoking, and sedentary lifestyle) that predispose them to suffer specific pathologies. Due to abnormalities in brain structure and functioning, people with intellectual disabilities suffer epilepsy more frequently. Finally, certain genetic disorders involve anomalies in the functioning of some organs or systems, either congenitally or over the years.

\section{Respiratory diseases}

They represent one of the leading causes of death in people with intellectual disabilities, although many of them can be prevented with primary care. One of the primary respiratory pathologies is pneumonia, very prevalent in the segment of people with severe intellectual disability and those with associated physical problems. In all these cases are frequent feeding problems mainly dysphagia, which leads to a risk of aspiration pneumonia, secondary to choking.

\section{Cardiovascular diseases}

Most people with intellectual disabilities suffer from congenital heart diseases (coarctation of the aorta, ventricular, or atrial septal defects) that can be diagnosed at birth or remain asymptomatic until adulthood. Many of these congenital diseases are usually associated with genetic syndromes, the most common being Down syndrome, Turner syndrome or Williams syndrome, and Di George syndrome. However, they can also present non-congenital heart diseases attributable to the presence of other risk factors such as obesity, high blood pressure, and a sedentary lifestyle, prevalent in people with intellectual disabilities.

\section{Digestive diseases}

Gastroesophageal reflux affects approximately half of the population with intellectual disability, mainly the 
severe type, frail $X$ syndrome, and those who suffer severe scoliosis. Although gastroesophageal reflux is easily treated, the main problem is the difficulty of diagnosis due to the difficulties for explaining the symptoms. Gastroesophageal reflux should be suspected in those who have negative attitudes about food intake, discomfort after eating, self-injurious behavior, cough at bedtime, tooth erosion, iron deficiency anemia, or weight loss. Constipation is also a very prevalent pathology in people with intellectual disabilities (especially for those with severe disabilities), attributable to immobility, hydration deficits, a restricted or low-fiber diet, and anticonvulsant medications ${ }^{16}$.

\section{Overweight and obesity}

One of the foremost public health concerns of the $21^{\text {st }}$ century is the obesity. $70 \%$ of obese adolescents remain obese adults with physiological, psychological, and social consequences ${ }^{19}$. Obesity is associated with a higher incidence of health problems in people with intellectual disabilities, including decreased social, physical, and quality functioning of life, difficulty in establishing relationships and stigma and discrimination between young people with and without disabilities ${ }^{20}$. Obesity in people with intellectual disabilities is one of the many characteristics used to measure inequality in health compared to the general population. It is likely that obesity contributes to increasing disparities, that is, high rates of mortality and undetected health need ${ }^{19}$. In addition to this, people with intellectual disabilities who are obese have an increased risk of diabetes, a situation that it can be exacerbated by the consumption of certain psychotropic drugs, especially some atypical antipsychotics.

\section{Infectious diseases}

Infectious diseases in people with intellectual disabilities are more prevalent mainly due to behaviors that may be frequent such as incorrect hand washing or taking things to the mouth, as well as some residential environments and immune deficits characteristic of certain hereditary diseases. Communication difficulties impact whether the diagnosis of infections is delayed or not diagnosed, worsening the prognosis, and increasing the risk of mortality. Examples of frequently underdiagnosed infections in people with intellectual disabilities are pneumonia and endocarditis. In hospital and residential contexts, it is advisable to pay attention to the prevention of infectious pathology through hygienic norms and vaccination, as well as the establishment of protocols for rapid action against possible contagious outbreaks.

\section{Genitourinary diseases}

A higher incidence of prostate and urinary tract cancer has been reported in men with intellectual disability compared to those who do not possess this condition. Furthermore, higher rates of testicular neoplasms have been observed in men with severe intellectual disability, probably due to the more significant presence of genetic alterations in germ cells. For women with intellectual disability problems of dysmenorrhea, menorrhagia, and amenorrhea should be considered, as well as pay particular attention to the hygiene problems associated with menstruation. When it comes to behavior problems in menstruating women, it should always be kept in mind that in the premenstrual stage or during the days of menstruation, discomfort or pain can be associated with self-aggressive or heteroaggressive behaviors (mainly in people with communication difficulties or severe intellectual disabilities). The incidence of cervical cancer in women with intellectual disabilities is very low (mostly in institutionalized settings). However, given that women with intellectual disabilities are increasingly likely to be active on a sexual level, the relevance of screening for cervical cancer in those considered necessary according to their sexual habits should be considered ${ }^{16}$.

\section{Neurological diseases}

Epilepsy is a neurological condition, particularly common in people with intellectual disabilities. For this population, prevalence rates range between 20 and $30 \%$, increasing with the severity of the intellectual disability ${ }^{21}$. Studies suggest that approximately one in five people with intellectual disabilities will have epilepsy except for people with Down syndrome in whom the rate is lower with about one in 10 people in adulthood ${ }^{22}$.

\section{Sensory problems}

The hearing and vision problems in people with intellectual disabilities are often underdiagnosed, mainly due to the difficulties to realize and express them and the problems of making a careful assessment. These deficits will mean for people with intellectual disabilities a decrease in communication skills and a significant worsening in their quality of life. Ear problems are poorIy diagnosed and poorly treated. It must be remembered that a frequent cause of hearing loss is impaction of earplugs in the ear canals ${ }^{16}$. 


\section{Oral problems}

The dental treatment is contraindicated in conditions of little cooperation of the patient or parents because it is difficult to obtain a positive result; besides, iatrogenesis in the event of caries and gingival inflammation is likely. Therefore, oral hygiene is the crucial factor that determines whether or not to perform the treatment because the minimal manual ability, accompanied by poor muscle activity, can be very harmful to the patient. Other common obstacles are typical behavior, excessive limb movement, low level of cooperation, and altered nausea reflex. All these affect negatively, from the taking of X-rays and impressions for appliances to the treatment itself. Reports on the oral health of people with intellectual disabilities have identified problems such as poor oral hygiene, untreated caries, and a high prevalence of periodontal disease. In addition to worse overall health, people with intellectual disabilities experience more difficulties in obtaining dental care than people in the general population, with a significant proportion of teeth extracted and a higher prevalence of traumatic dental injuries. A good promotion of oral health can reduce the burden of diseases such as dental caries, gingivitis, and periodontal disease that is among the highest secondary conditions in people with intellectual disabilities that cause limitations in their daily activities. The oral health of these people in many cases depends on a large extent on the knowledge, attitudes, and practices of their family members or care providers. Motor impairments are a limiting factor for access to treatments ${ }^{23}$.

\section{Conclusions}

The approach to intellectual disability, whether to define a therapeutic strategy or design a research proto$\mathrm{col}$, is a multifaceted process. This complexity can be observed in the moment of determining operationally the intellectual disability, as well as the variability of concomitant conditions that can affect the outcome of an intervention. The health area staff should consider the possible involvement of numerous systems; the therapist, the diversity of behavior; and the researcher, the potential variables that may influence their object of study. However, with adequate strategies and designs, the health professionals involved in the approach of people with intellectual disabilities will be able to generate knowledge, in such a way that substantial improvements in the quality of life of this group will be achieved shortly.

\section{Conflicts of interest}

The authors declare that in this study, there are no relevant conflicts of interest.

\section{Funding}

There was no particular funding source for this scientific report.

\section{References}

1. Lima-Rodríguez JS, Baena-Ariza MT, Domínguez-Sánchez I, Lima-Serrano $\mathrm{M}$. Intellectual disability in children and teenagers: influence on family and family health. Systematic review. Enferm Clin. 2018;28:89-102.

2. Havercamp SM, Scott HM. National health surveillance of adults with disabilities, adults with intellectual and developmental disabilities, and adults with no disabilities. Disabil Health J. 2015;8:165-72.

3. Mundial B. Informe mundial la discapacidad. Educación. 2011:218:219.

4. Fernández-López JA, Fernández-Fidalgo M, Geoffrey R, Stucki G, Cieza A. Funcionamiento y discapacidad: la clasificación internacional del funcionamiento (CIF). Rev Esp Salud Publica. 2009;83:775-83.

5. NOM-015-SSA3-2012, Para la Atención Integral a Personas con Discapacidad, 015-SSA3-2012 Documents; 2012.

6. Navas P, Verdugo M, Gómez L. Diagnóstico y clasificación en discapacidad intelectual. Psychosoc Interv. 2008;17:143-52.

7. Üstün B. Disability and Culture: universalism and Diversity. Seattle: Hofgre and Huber; 2001.

8. Schalock RL, Borthwick-Duffy SA, Bradley VJ, et al. Intellectual Disability: definition, Classification, and Systems of Supports. Arlington, VA: ERIC; 2010.

9. Ladrón A, Álvarez M, Sanz L, Antequera J, Muñoz J, Almendro M. DSM5: novedades y Criterios Diagnósticos. 2013;205:20. Available from: http://www.codajic.org/sites/www.codajic.org/files/DSM\%205\%20\%20 Novedades\%20y\%20Criterios\%20Diagnósticos.pdf [Last access: 2018 Nov 18. Verified: 2019 Apr 5].

10. Simms M. Intellectual and developmental disability. In: Kliegman RM, Lye PS, Brdini BJ, Toth H, Basel D, editors. Nelson Pedriatrics Symptom-Diagnosis. Philadelphia, PA: Elsevier; 2018. p. 929.

11. Videa $P$, de los Angeles R. Comprendiendo la discapacidad intelectual: datos, criterios y reflexiones. Rev Investig Psicol. 2016;15:101-22.

12. Barrios JA, González-Gordon RG, Ruiz JP, et al. Evaluación médica y psicosocial de una población adulta con discapacidad intelectual. Rev Esp Salud Publica. 1999;73:383-92.

13. Instituto Nacional de Estadistica y Geografia. In: Geografia IN, editor. La Discapacidad en México, Datos al 2014. México: Instituto Nacional de Estadistica y Geografia; 2016. p. 358.

14. García CE, Sánchez AS. Clasificaciones de la OMS sobre discapacidad. Bol R Patronate Discapacidad. 2001;50:15-30.

15. Muñoz-Quezada MT, Lucero Mondaca B. Evaluación de procedimientos para el diagnóstico de discapacidad intelectual en estudiantes con discapacidades múltiples. Ajayu Órgano Difusión Científica Dep Psicol UCBSP. 2017;15:34-52.

16. Planagumà LV, Alsina RN, Llop RG, Vidal NR. In: Salut GD, editor. La Salud de Las Personas con Discapacidad Intelectual: ¿qué Debemos Tener en Cuenta? Guía Práctica Para Profesionales de la Salud. Ampans: Servei d'Imprenta; 2013.

17. Martínez-Leal R, Salvador-Carulla L, Gutiérrez-Colosía MR, et al. La salud en personas con discapacidad intelectual en España: estudio Europeo POMONA-II. Rev Neurol. 2011;53:406-14.

18. Matson JL, Cervantes PE. Comorbidity among persons with intellectual disabilities. Res Autism Spectr Disord. 2013;7:1318-22

19. Krause S, Ware R, McPherson L, Lennox N, O'Callaghan M. Obesity in adolescents with intellectual disability: prevalence and associated characteristics. Obes Res Clin Pract. 2016;10:520-30.

20. Rimmer JH, Yamaki K, Lowry BM, Wang E, Vogel LC. Obesity and obesity-related secondary conditions in adolescents with intellectual/ developmental disabilities. J Intellect Disabil Res. 2010;54:787-94.

21. van Ool JS, Snoeijen-Schouwenaars FM, Schelhaas HJ, et al. A systematic review of neuropsychiatric comorbidities in patients with both epilepsy and intellectual disability. Epilepsy Behav. 2016;60:130-7.

22. Robertson J, Hatton C, Emerson E, Baines S. Prevalence of epilepsy among people with intellectual disabilities: a systematic review. Seizure. 2015;29:46-62.

23. Petrovic BB, Peric TO, Markovic DL, et al. Unmet oral health needs among persons with intellectual disability. Res Dev Disabil. 2016;59:370-7. 